\title{
INVESTIGATING THE CONNECTIONS BETWEEN NIGHT EATING SYNDROME AND METABOLIC SYNDROME IN CHILDREN
}

\author{
H. A. PAVLYSHYN, K. V. KOZAK ${ }^{凶}$, K. T. HLUSHKO \\ Department of Pediatrics No 2, I. Horbachevsky Ternopil National \\ Medical University, Ternopil, Ukraine; \\ 凶e-mail: kozakk@tdmu.edu.ua
}

Received: 29 January 2021; Accepted: 23 April 2021

Eating disorders are considered to be the cause of obesity, particularly its abdominal type and metabolic syndrome (MS). Until recently, night eating syndrome (NES) and MS were documented only in the adult population, but nowadays they are also seen among children. Therefore, the aim of our study was to determine the association between NES and MS. A total of 120 overweight (18.33\%) and obese (81.67\%) children 10-17 years of age were examined (27 girls (22.5\%) and 93 boys (77.5\%)). Anthropometric and blood pressure measurements were performed for all children. Serum triglycerides, high-density lipoproteins and glucose levels were assessed. Abdominal obesity was found in $70 \%$ of cases. NES was diagnosed in $20.83 \%$ of children. MS was found in 34.17\% of participants. MS was more prevalent in the NES group (56.00\% (95\% CI 30.62; 93.96)), compared with the non-NES group (28.42\% (95\% CI 18.73; 41.35)) ( $P<0.05)$. NES increases the risk of MS development by 3 times (OR 3.21 (95\% CI 1.29-7.94); P = 0.012). Based on these results, careful screening for eating behavior and especially NES should be an integral part of the examination of overweight and obese children with the aim of timely diagnosis of MS.

Ke y w o r d s: night eating syndrome (NES), metabolic syndrome (MS), children.

\section{Introduction}

The global prevalence of obesity has been increasing in recent years; in 2016, it was reported in $6 \%$ of girls and $8 \%$ of boys [1, 2]. In 2016, a total of 340 million children were overweight or obese worldwide [1]. It is not new knowledge that overweight and obesity in childhood lead to many metabolic consequences, and as a result to the development of chronic diseases, such as cardiovascular pathology, diabetes, cancer, orthopedic, gynecological, and psychiatric problems [1-3]. All of these health issues are accompanied by poor quality of life and shorter life expectancy [2]. Notably, pediatric endocrinologists have emphasized that overweight or obese patients should be screened for comorbidities, such as prediabetes and diabetes, dyslipidemia, hypertension, non-alcohol fatty liver disease, polycystic ovarian syndrome, obstructive sleep apnea and psychiatric disorders [3]. This fact emphasizes the importance of early detection of metabolic and behavioral changes in childhood to prevent the appearance of diseases later in life. At the same time, some of the listed comorbidities (arterial hypertension, hyperglycemia, dyslipidemia) are accompanied by the metabolic syndrome (MS), which has been diagnosed as early as 10 years of age [4-6].

Current reports have suggested that the leading causes of overweight and obesity are decreased physical activity, unhealthy diet and disturbances in sleeping patterns [3]. It is noteworthy that changes in eating behavior and circadian rhythms are becoming very important contributing factors to obesity development [7]. One of the most discussed eating disorders in recent decades is night eating syndrome (NES) $[8,9]$. NES is the combination of nighttime eating and alterations in sleeping patterns [10, 11]. Furthermore, until recently, NES and MS were reported only in the adult population, but nowadays

(C) 2021 Pavlyshyn H. A. et al. This is an open-access article distributed under the terms of the Creative Commons Attribution License, which permits unrestricted use, distribution, and reproduction in any medium, provided the original author and source are credited. 
they can also be seen among children. The prevalence of NES among the normal weight adult population tends to be $0.5-1.5 \%$ while in the obese group it is $15-25 \%$ [9].

Many publications have confirmed the association between NES and weight gain. Nevertheless, previously conducted surveys focused on the adult population, including patients with mental and psychiatric disorders or those who were undergoing treatment (weight loss therapy, bariatric surgery) $[8,12]$. Taking into account the fact that obesity and especially its abdominal type is the basis for MS development, the aim of our study was to explore interrelationships between eating disorders (i.e., NES) and MS. Current studies have focused on the connection between binge eating in children and MS. However, they have not focused specifically on NES, and the criteria which were used to diagnose MS did not correspond to current knowledge [13]. In addition, specific disease groups were not studied. Therefore, all current classifications of NES and MS were considered in the basis of our research in order to establish any association between them in a specific pediatric overweight/obese population.

\section{Materials and Methods}

A total of 120 overweight and obese children 10-17 years of age were examined (27 girls [22.5\%] and 93 boys [77.5\%]). The study was performed at Ternopil Regional Hospital, Ukraine. Inclusion criteria were the children's overweight or obesity, and presence of informed consent. Informed consent was received from every child and his/her legal representatives (in our study - parents). A study was conducted based on all ethical principles for medical research involving human subjects (Declaration of Helsinki, 2013) and was confirmed by the Bioethics Commission of the I. Horbachevsky Ternopil State Medical University (Protocol No. 24 from August 27, 2014).

Exclusion criteria were the presence of secondary obesity (endocrine and genetic), or diseases requiring medication that affects carbohydrate and lipid metabolism or stimulates appetite.

Anthropometric measurements (weight, height, waist circumference [WC]) were performed on all children. The accuracy in measurements was weight to the nearest $0.1 \mathrm{~kg}$, height to the nearest $0.001 \mathrm{~m}$ and WC to the nearest $0.005 \mathrm{~m}$.

Body mass index (BMI) was calculated by the formula:
$\mathrm{BMI}=\mathrm{m} / \mathrm{h}^{2}$,

where $\mathrm{m}$ - weight of the child (kg); $\mathrm{h}$ - height of the child (m).

Evaluation of overweight and obesity was done according to Centers for Disease Control and Prevention Recommendations and Endocrine Society clinical practice guideline [3, 14]. Overweight was diagnosed when BMI was at or above the $85^{\text {th }}$ percentile and less than the $95^{\text {th }}$ percentile based on the age- and gender-specific charts. Obesity was defined when BMI was equal to or exceeded the $95^{\text {th }}$ percentile, based on age and gender.

WC was assessed based on age and genderspecific nomograms and The International Diabetes Federation Consensus recommendations (2007) [4]. In children aged 10-16 years, abdominal obesity $\mathrm{AO}$ ) was diagnosed when WC was equal to or greater than the $90^{\text {th }}$ percentiles according to age and gender, or based on adult cut-off points, whichever was lower. In children older than 16 years, $\mathrm{AO}$ was confirmed when WC was equal to or exceeded $94 \mathrm{~cm}$ in boys and $80 \mathrm{~cm}$ in girls.

Blood pressure (BP) was measured after $10 \mathrm{~min}$ of rest in the sitting position. Measurements were repeated twice and the average result was noted. Age-appropriate cuffs were used. High-density lipoproteins (HDL-C) and triglycerides (TG) were measured in blood serum using the enzyme method with reagents from Human GmbH (Wiesbaden, Germany). The glucose oxidase method was used to estimate the serum glucose level. A blood sample was taken on an empty stomach and without any diet restrictions at 2 weeks prior to examination. BP, HDL-C, TG and glucose level assessments were done based on the MS criteria.

The leptin level was assessed using an immunoassay method (DRG Leptin [sandwich] ELISA Kit, DRG International, Marburg, Germany). Based on the instruction manual, the normal ranges were 2.05-5.63 $\mathrm{ng} / \mathrm{ml}$ for boys and 3.63-11.09 $\mathrm{ng} / \mathrm{ml}$ for girls.

MS for children aged 10 years to less than 16 years was defined in cases of $\mathrm{AO}$ and presence of 2 or more of the following criteria: 1) TG level $\geq 1.7 \mathrm{mmol} / \mathrm{l}$; 2) HDL-C level $<1.03 \mathrm{mmol} / \mathrm{l}$; 3) Systolic BP (SBP) $\geq 130 \mathrm{~mm} \mathrm{Hg}$, diastolic BP (DBP) $\geq 85 \mathrm{~mm} \mathrm{Hg}$; 4) Serum glucose level $\geq 5.6 \mathrm{mmol} / \mathrm{l}$ [4].

MS in children aged 16 years or older was defined in cases of $\mathrm{AO}$ and presence of 2 or more of the following criteria: 1) TG level $\geq 1.7 \mathrm{mmol} / 1$; 2) HDL-C level $<1.03 \mathrm{mmol} / 1$ in boys and $<1.29$ 
$\mathrm{mmol} / \mathrm{l}$ in girls; 3) SBP $\geq 130 \mathrm{~mm} \mathrm{Hg}$; DBP $\geq 85 \mathrm{~mm}$ $\mathrm{Hg}$; 4) Serum glucose level $\geq 5.6 \mathrm{mmol} / 1$ [4].

NES was diagnosed based on the following criteria [15]:

A. Presence of one or both of the following:

1. At least $25 \%$ of daily food intake was consumed after the evening meal; week.

2. At least 2 episodes of nighttime eating per

B. Presence of awareness and recall of evening and nocturnal eating.

C. Presence in the clinical presentation of at least three of the following:

1. Absence of desire to eat in the morning and breakfast skipping four or more times per week;

2. Presence of strong desire to eat between dinner and going to sleep and/or during the night;

3. Presence of sleep onset and/or sleep insomnia four or more times per week;

4. Presence of belief that one must eat in order to initiate or return to sleep;

5. Mood that was depressed or worsened in the evening.

D. The disorder was associated with significant distress and/or impairment in functioning.

E. Maintenance of disordered eating for at least 3 months.

F. The disorder was not secondary to substance abuse or dependence, medical disorder, medication, or another psychiatric disorder.

Statistical analysis was performed using the computer software packages STATISTICA 7.0 and Microsoft Excel [16, 17]. Qualitative parameters were expressed as percentages with a $95 \%$ confidence interval (CI). Quantitative indices were presented as the mean \pm standard deviation (Mean \pm SD) in cases of normal distributions, and as median (lower quartile; upper quartile) [Me (Lq; Uq)] in cases of non-normal distributions. Comparisons of two independent values with normal distribution were made using the $t$-test. Comparisons of two independent values with non-normal distributions were made using the Mann-Whitney test. The Fisher exact two-tailed test was used to compare $2 \times 2$ frequency tables. The difference test for two proportions was used. To study the possibility of outcome developments, the odds ratio and its 95\% CI were calculated. The influence of NES on MS components was assessed by logistic regression. Wald test was used to find out the statistical significance of logistic regres- sion coefficients. Statistically significant results were considered to be cases of $P<0.05$.

\section{Results}

There were 98 obese (81.67\%) and 22 overweight $(18.33 \%)$ children examined (Table 1$)$. Based on age, they were divided into 2 groups: group 1 children $10-15$ years of age $(n=44,(36.67 \%))$ and group 2 - children 16 years of age and older $(n=76$, (63.33\%)). There were no differences in gender presentation between overweight and obese patients $(P>0.05)$. There were $22.73 \%$ girls and $77.55 \%$ boys in the overweight group; and $22.45 \%$ and $77.55 \%$, respectively, in the obese group. Male gender was more prevalent among the older age group $(P<0.001)$.

The abdominal type of obesity was observed in 84 patients (70.00\% (95\% CI 55.83; 86.60)) (Table 1). Frequency of $\mathrm{AO}$ was significantly higher in the obese group compared with their overweight peers ( $80.61 \%$ vs. $22.73 \%$, respectively, $P<0.001$ ). There was a significant gender difference in the $\mathrm{AO}$ rate, as AO was found more often in boys (75.27\%) than in girls $(51.85 \%)(P=0.031)$.

SBP and DBP levels were significantly higher among obese children, children of age 16-17 years and boys (Table 2). The total number of children with $\mathrm{SBP} \geq 130 \mathrm{~mm} \mathrm{Hg}$ was $76(63.33 \%$ (95\% CI $49.90 ; 79.27)$ ), and with DBP $\geq 85 \mathrm{~mm} \mathrm{Hg}$ was 44 (36.67\% (95\% CI 26.64; 49.22)). Analysis of BP level based on the MS criteria showed that high SBP was more prevalent among boys $(P=0.012)$. For DBP there was no significant gender difference $(P>0.05)$. High SBP $\geq 130 \mathrm{~mm} \mathrm{Hg}$ was more typical for children older than 16 years $(P=0.003)$ and was more prevalent among the obese group $(P=0.026)$. There were no significant age or weight-related differences for high DBP $(P>0.05)$. Prevalence of elevated SBP was significantly higher in the group with AO (72.62\% [95\% CI 55.55; 93.28]) than in the group without AO (41.67\% (95\% CI 23.32; 68.72)) $(P=0.002)$. DBP $\geq 85 \mathrm{~mm} \mathrm{Hg}$ was seen in $25.00 \%$ (95\% CI 11.43; 47.65) of the group without $\mathrm{AO}$ and in $41.67 \%$ (95\% CI 29.02; 57.95) of the group with $\mathrm{AO}(P>0.05)$.

Based on the biochemical parameter assessment (HDL-C, TG, glucose), gender and age differences between study groups were found (Table 3). Boys had significantly lower levels of HDL-C compared to girls $(P=0.005)$. The glucose level increased with age $(P=0.035)$. 
Ta b le 1. Characteristics of overweight and obese children $(n=120)$

\begin{tabular}{l|c|c|c|c}
\hline \multicolumn{1}{c|}{ Parameter } & All $(n=120)$ & $\begin{array}{c}10-15 \text { years } \\
(n=44)\end{array}$ & $\begin{array}{c}16 \text { years and } \\
\text { older }(n=76)\end{array}$ & $P / P_{\mathrm{F}}^{2,3,4}$ \\
\hline Boys, $n$ (\%) & $93(77.50)^{1}$ & $23(52.27)$ & $70(92.11)$ & $P_{\mathrm{F}}<0.001^{*}$ \\
Girls, $n$ (\%) & $27(22.50)$ & $21(47.73)$ & $6(7.89)$ & $P_{\mathrm{F}}<0.001^{*}$ \\
Obesity, $n$ (\%) & $98(81.67)$ & $33(75.00)$ & $65(85.53)$ & $P_{\mathrm{F}}=0.220$ \\
Overweight, $n$ (\%) & $22(18.33)$ & $11(25.00)$ & $11(14.47)$ & $P_{\mathrm{F}}=0.220$ \\
Abdominal obesity, $n$ (\%) & $84(70.00)$ & $26(59.09)$ & $58(76.32)$ & $P_{\mathrm{F}}=0.062$ \\
Weight, kg & $89.73 \pm 18.88^{1}$ & $78.89 \pm 22.88$ & $95.42 \pm 13.25$ & $P<0.001^{*}$ \\
Height, m & $1.71 \pm 0.11$ & $1.64 \pm 0.13$ & $1.75 \pm 0.08$ & $P<0.001^{*}$ \\
Body mass index (BMI), kg/m ${ }^{2}$ & $30.45 \pm 4.28$ & $29.33 \pm 5.18$ & $31.09 \pm 3.55$ & $P=0.029^{*}$ \\
Waist circumference (WC), cm & $98.25 \pm 11.86$ & $94.18 \pm 14.80$ & $100.61 \pm 9.07$ & $P=0.004^{*}$ \\
\hline
\end{tabular}

Note. ${ }^{1}$ Qualitative data are presented as number (\%); quantitative data are presented as Mean \pm SD. ${ }^{2} P$ - level of statistical significance for $t$-test for independent samples by variables; $P$ value - for comparison of weight, height, BMI and WC between age groups. ${ }^{3} P_{\mathrm{F}}-$ level of significance for two-tailed Fisher exact test; $P_{\mathrm{F}}-$ for comparison of gender and weight status between age groups. ${ }^{4 *}$ Statistically significant results

Ta ble 2. Blood pressure characteristics depending on weight status, age and gender of the children

\begin{tabular}{|c|c|c|c|c|c|c|}
\hline Groups & $\mathrm{SBP}, 2 \mathrm{~mm} \mathrm{Hg}$ & $\begin{array}{c}\text { SBP } \\
\geq 130 \mathrm{~mm} \\
\mathrm{Hg}, n(\%)\end{array}$ & $\begin{array}{c}\text { SBP } \\
<130 \mathrm{~mm} \\
\mathrm{Hg}, n(\%)\end{array}$ & $\begin{array}{c}\text { DBP, } \\
2 \text { mm Hg }\end{array}$ & $\begin{array}{c}\text { DBP } \\
\geq 85 \mathrm{~mm} \\
\mathrm{Hg}, n(\%)\end{array}$ & $\begin{aligned} & \mathrm{DBP} \\
&< 85 \mathrm{~mm} \\
& \mathrm{Hg}, n(\%)\end{aligned}$ \\
\hline Overweight & $125.23 \pm 13.58^{1}$ & $9(40.91)^{1}$ & 13 (59.09) & $78.18 \pm 6.82$ & 4 (18.18) & $18(81.82)$ \\
\hline Obesity & $132.70 \pm 14.99$ & 67 (68.37) & 31 (31.63) & $82.96 \pm 8.64$ & $40(40.82)$ & 58 (59.18) \\
\hline$P$ & $P=0.034^{* 3,4}$ & \multicolumn{2}{|c|}{$P_{\mathrm{F}}=0.026^{* 3,4}$} & $P=0.017^{*}$ & \multicolumn{2}{|c|}{$P_{\mathrm{F}}=0.053$} \\
\hline $\begin{array}{l}\text { Age group } \\
10-15 \text { years }\end{array}$ & $125.45 \pm 15.66$ & $20(45.45)$ & $24(54.55)$ & $79.43 \pm 8.84$ & $11(25.00)$ & $33(75.00)$ \\
\hline $\begin{array}{l}\text { Age group } \\
16-17 \text { years }\end{array}$ & $134.74 \pm 13.54$ & $56(73.86)$ & $20(26.14)$ & $83.62 \pm 7.98$ & 33 (43.42) & 43 (56.58) \\
\hline$P$ & $P<0.001^{*}$ & \multicolumn{2}{|c|}{$P_{\mathrm{F}}=0.003^{*}$} & $P=0.009^{*}$ & \multicolumn{2}{|c|}{$P_{\mathrm{F}}=0.051$} \\
\hline Boys & $133.71 \pm 14.89$ & 65 (69.89) & 28 (30.11) & $83.06 \pm 8.31$ & 37 (39.78) & $56(60.22)$ \\
\hline Girls & $123.15 \pm 12.34$ & 11 (40.74) & 16 (59.26) & $78.70 \pm 8.50$ & 7 (25.93) & $20(74.07)$ \\
\hline$P$ & $P=0.001^{*}$ & \multicolumn{2}{|c|}{$P_{\mathrm{F}}=0.012 *$} & $P=0.019^{*}$ & \multicolumn{2}{|c|}{$P_{\mathrm{F}}=0.257$} \\
\hline
\end{tabular}

Note. ${ }^{1}$ Qualitative data are presented as number (\%); quantitative data are presented as Mean \pm SD. ${ }^{2} \mathrm{SBP}-$ systolic blood pressure; DBP - diastolic blood pressure. ${ }^{3} \mathrm{P}$ - level of statistical significance for $t$-test for independent samples by variables; $P_{\mathrm{F}}-$ level of statistical significance for Fisher exact two-tailed test. ${ }^{4}$ *Statistically significant results

The number of children with HDL-C levels corresponding to the MS criteria was $24(20.00 \%$ (95\% CI 12.81; 29.76)). Low HDL-C level was found more often among adolescents aged 16-17 years $(P=0.008)$ and males $(P=0.014)$ (Table 3$)$. There was no statistically significant difference in the frequency of low HDL-C between obese and overweight children $(P>0.05)$. Nevertheless, chil- dren with AO more often had low HDL-C (25.00\% (95\% CI 15.48; 38.22)) compared to those without AO (8.33\% [95\% CI 1.72; 24.35]) $(P=0.037)$.

A high level of TG was found in 18 children (15\% (95\% CI 8.89; 23.71)). There were no dissimilarities in hypertriglyceridemia frequencies between age and gender groups, or between overweight and obese groups $(P>0.05)$ (Table 3$)$. Also, there was 


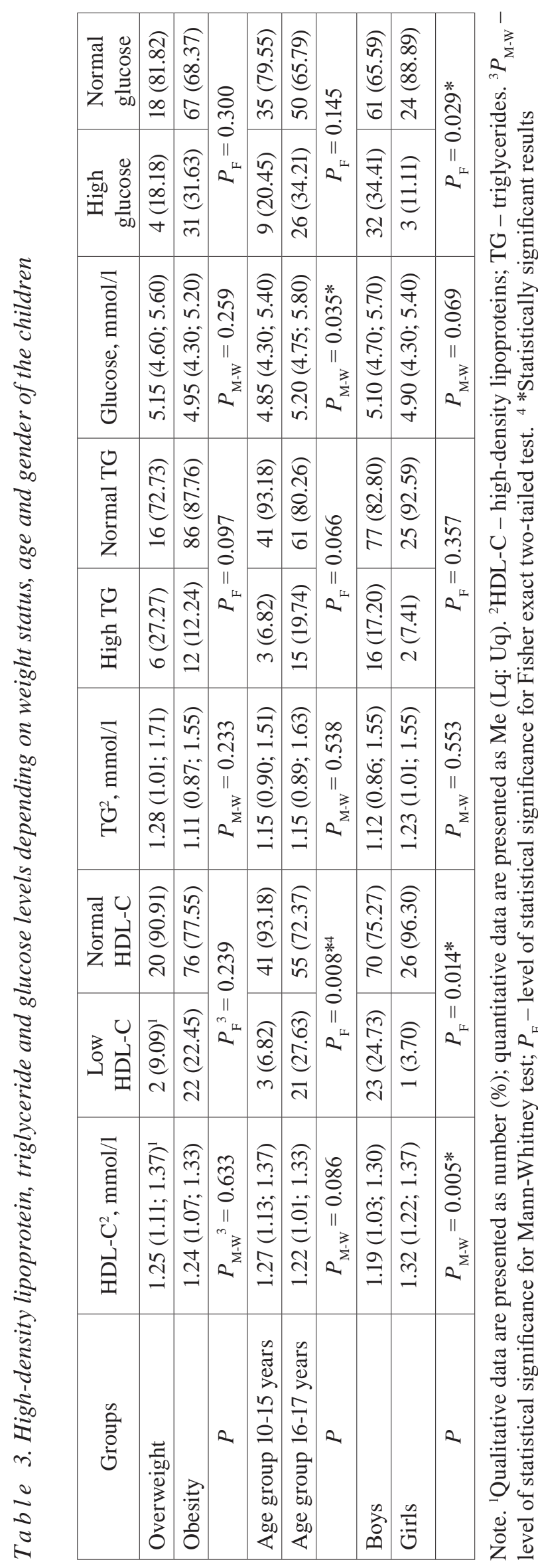

no significant difference in hypertriglyceridemia frequency between the AO group (15.48\% (95\% CI $8.24 ; 26.46))$ and the group without AO (13.89\% (95\% CI 8.24; 26.46)) $(P>0.05)$.

Hyperglycemia $(\geq 5.6 \mathrm{mmol} / \mathrm{l})$ was found in 35 children, with a higher frequency in boys $(P=0.029)$. There was no significant difference in the glucose level between age and overweight/obese groups $(P>0.05)$ (Table 3$)$. There were no significant differences in prevalence of hyperglycemia between the groups with $\mathrm{AO}$ and without $\mathrm{AO}$ (30.95\% (95\% CI 20.22; 45.35) vs. and 25.00\% (95\% CI 11.43; 47.46)) $(P>0.05)$.

Based on the proposed criteria, MS was found in 41 children (34.17\% (95\% CI 24.52; 46.35)), with statistically higher prevalence in boys $(P<0.001)$. NES was diagnosed in 25 overweight/obese children (20.83\% (95\% CI 13.48; 30.75)), and statistically more often in girls $(P=0.029)$ (Figure). It should be noted that MS and NES were seen more often among obese adolescents than their overweight peers $(P<0.05)$. Age had no significant influence on the frequency of NES $(P>0.05)$. At the same time, MS was more prevalent in the older age group $(P=0.048)$.

Analysis of the main criteria of MS with regards to the presence or absence of NES showed that MS was found more often in the NES group than the non-NES group $(P<0.05)$ (Table 4$)$. Patients with NES had significantly higher WC and lower HDL-C levels compared to peers without this eating disorder. Despite the fact that all children were overweight or obese, participants with NES had significantly higher BMI compared to those without NES $\left(33.48 \pm 5.54 \mathrm{~kg} / \mathrm{m}^{2}\right.$ vs. $29.64 \pm 3.50 \mathrm{~kg} / \mathrm{m}^{2}$, respectively; $P<0.001)$. Notably, almost all patients (92\% (95\% CI 58.32; 100.00)) with diagnosed NES had at least one diagnostic criterion of MS and only 2 girls with NES (8\% (95\% CI 0.97; 28.90)) had no MS criteria.

Analysis of the frequencies of NES and MS based on the presence or absence of the main MS criteria showed that NES is found more often when AO is present (Table 5). Analysis of NES in children with low HDL-C showed it is significantly more prevalent than in children with normal values of HDL-C.

In order to explore similarities in the pathogenesis of NES and MS, serum levels of the adipokine leptin were measured (Table 6). Taking into account the fact that hyperleptinemia was diagnosed in 22 


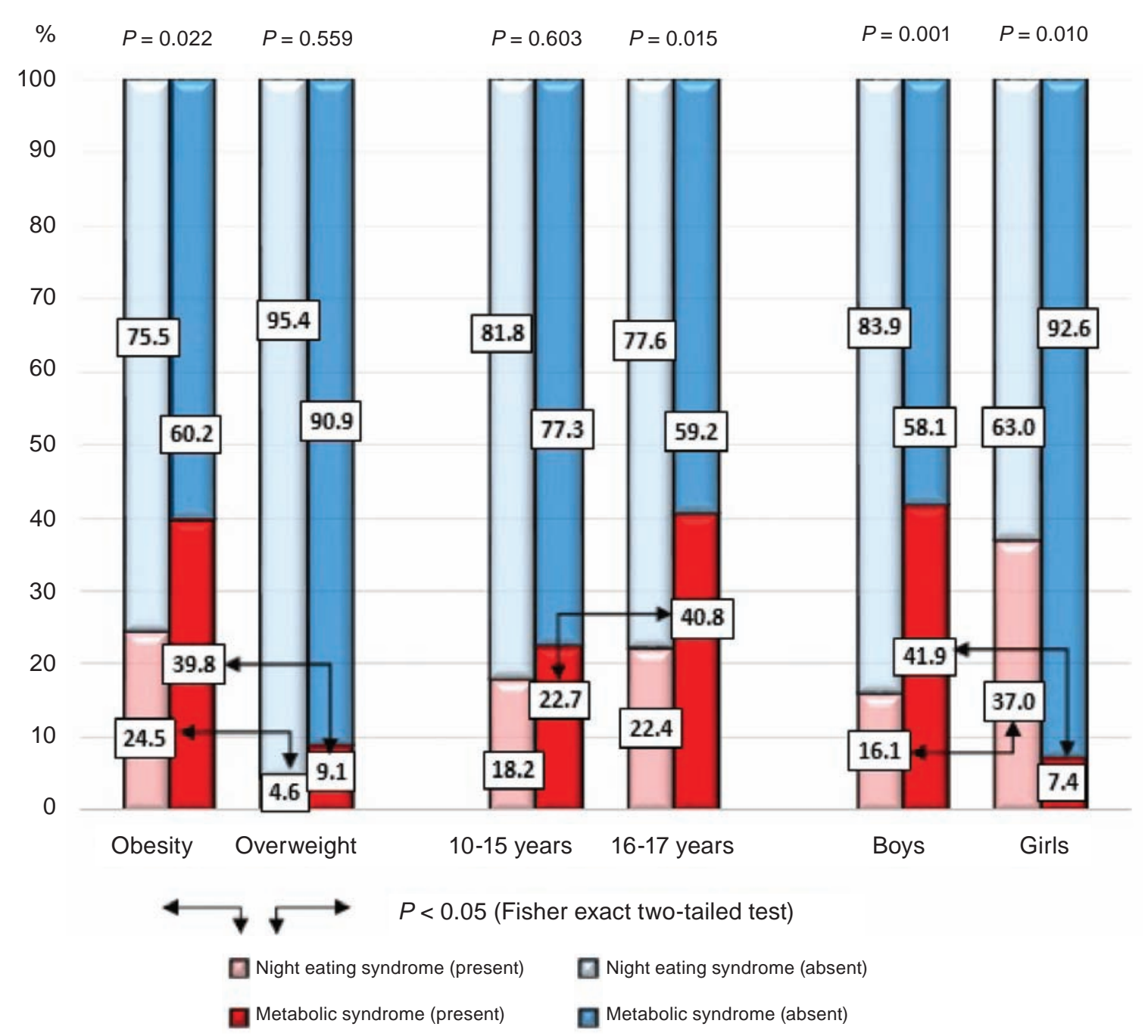

Prevalence of night eating syndrome and metabolic syndrome depending on weight status, age and gender of the children

children (18.33\%), we compared the leptin level in the presence or absence of NES and MS. The leptin level was significantly higher among the NES group than the non-NES group, and its higher level was also more typical for the NES group. In addition, the leptin level was significantly higher in the NES group than in the MS group (4.98 vs. $3.84 \mathrm{ng} / \mathrm{ml}$; $P=0.043$ ).

NES in overweight and obese children increased the risks of MS by 3.21 times, of AO by 3.9 times and of decreased HDL-C levels by almost 5 times (Table 7).

\section{Discussion}

The results of our study have confirmed the high prevalence of NES among overweight and obese children, which correlates with data obtained by other scientists $[18,19]$. Based on different surveys, NES occurs in 5-20\% of the general population; its prevalence significantly depends on the type of study (longitudinal or cross-sectional) and selected group [20, 21].

Appearance of overweight in the case of NES could be explained by increased food consumption in the absence of adequate energy expenditure $[8,22]$. Not only the amount of food consumed in the evening but also its type can significantly influence the weight gain. It should be emphasized that some researchers believe that lower socio-economic status increases the access to food that is easy available but rich in fats and carbohydrates [8, 23]. In addition, increased sleep onset time and increased frequency of night awakenings are obesity-contributing factors. Longer times without sleep in turn lead to an 
Ta ble 4. Metabolic syndrome components in overweight and obese children with and without night eating syndrome

\begin{tabular}{|c|c|c|}
\hline \multirow{2}{*}{ Parameter } & \multicolumn{2}{|c|}{ Night eating syndrome } \\
\hline & present $(n=25)$ & absent $(n=95)$ \\
\hline Metabolic syndrome & $n=14,56.00 \%{ }^{1}\left(95 \% \mathrm{CI}^{2} 30.62 ; 93.96\right)^{* 3,4}$ & $n=27,28.42 \%(95 \%$ CI $18.73 ; 41.35)$ \\
\hline $\mathrm{WC}^{2}, \mathrm{~cm}$ & $109.22 \pm 12.96^{* 1}$ & $104.34 \pm 8.68$ \\
\hline $\mathrm{AO}^{2}$ & $n=22,88.00 \%(95 \% \text { CI } 55.15 ; 100.00)^{*}$ & $n=62,65.26 \%(95 \%$ CI $50.04 ; 83.66)$ \\
\hline $\mathrm{SBP}^{2}, \mathrm{~mm} \mathrm{Hg}$ & $131.16 \pm 14.26$ & $132.00 \pm 17.74$ \\
\hline High SBP & $n=15,60.00 \%(95 \%$ CI $33.58 ; 98.96)$ & $n=61,64.21 \%(95 \%$ CI $49.12 ; 82.48)$ \\
\hline $\mathrm{DBP}^{2}, \mathrm{~mm} \mathrm{Hg}$ & $82.00 \pm 8.10$ & $82.40 \pm 10.12$ \\
\hline High DBP & $n=10,40.00 \%(95 \%$ CI $19.18 ; 73.56)$ & $n=34,35.79 \%(95 \%$ CI $24.79 ; 50.01)$ \\
\hline $\mathrm{HDL}-\mathrm{C}^{2}, \mathrm{mmol} / \mathrm{l}$ & $1.09(0.96 ; 1.33)^{* 1}$ & $1.25(1.12 ; 1.37)$ \\
\hline Low HDL-C level & $n=11,44.00 \%(95 \%$ CI $21.96 ; 78.73) *$ & $n=13,13.68 \%(95 \%$ CI $7.29 ; 23.40)$ \\
\hline $\mathrm{TG}^{2}, \mathrm{mmol} / \mathrm{l}$ & $1.23(0.85 ; 1.59)$ & $1.12(0.90 ; 1.55)$ \\
\hline High TG & $n=4,16.00 \%(95 \%$ CI $4.36 ; 40.97)$ & $n=14,14.74 \%(95 \%$ CI $8.06 ; 24.73)$ \\
\hline Glucose, $\mathrm{mmol} / \mathrm{l}$ & $5.00(4.50 ; 5.60)$ & $5.20(4.60 ; 5.60)$ \\
\hline Hyperglycemia & $n=9,36.00 \%(95 \%$ CI $16.46 ; 68.34)$ & $n=26,27.37 \%(17.88 ; 40.01)$ \\
\hline
\end{tabular}

Note. ${ }^{1}$ Qualitative data are presented as number (\%); quantitative data are presented as Mean \pm SD or Me (Lq: Uq). ${ }^{2} \mathrm{CI}$ - confidence interval; WC - waist circumference; AO - abdominal obesity; SBP - systolic blood pressure; DBP diastolic blood pressure; HDL-C - high-density lipoproteins; TG - triglycerides. ${ }^{3}$ Statistical difference was assessed with $t$-test for independent samples by variables for parameters with normal distribution (WC, SBP, DBP); Mann-Whitney test for parameters with non-normal distribution (HDL-C, TG, glucose); $P$-value for difference tests between two proportions. ${ }^{4}$ *Statistically significant results

Table 5. Comparison of night eating syndrome and metabolic syndrome prevalence in overweight and obese children depending on the presence or absence of relevant metabolic syndrome criteria

\begin{tabular}{|c|c|c|c|c|c|c|c|}
\hline \multirow{2}{*}{\multicolumn{2}{|c|}{ Parameters }} & \multicolumn{3}{|c|}{ Night eating syndrome } & \multicolumn{3}{|c|}{ Metabolic syndrome } \\
\hline & & \multirow{2}{*}{$\begin{array}{l}n \\
3\end{array}$} & \multirow{2}{*}{$\begin{array}{c}\%\left(95 \% \mathrm{CI}^{3}\right) \\
8.33(1.72 ; 24.35)\end{array}$} & \multirow{3}{*}{$\begin{array}{c}P^{4} \\
0.029 * 5\end{array}$} & \multirow[t]{3}{*}{$n$} & \multirow{2}{*}{$\begin{array}{c}\%(95 \% \mathrm{CI}) \\
0\end{array}$} & \multirow{3}{*}{$\begin{array}{c}P \\
<0.001^{*}\end{array}$} \\
\hline \multirow{2}{*}{$\mathrm{AO}^{3}$} & absent $(n=36)$ & & & & & & \\
\hline & present $(n=84)$ & 22 & 26.19 (16.14; 39.65) & & & 48.81 (35.03; 66.22) & \\
\hline \multirow{2}{*}{$\uparrow \mathrm{SBP}^{3}$} & absent $(n=44)$ & 10 & $22.73(10.90 ; 41.80)$ & \multirow{2}{*}{0.816} & 6 & 13.64 (5.00; 29.68) & \multirow{2}{*}{$<0.001^{*}$} \\
\hline & present $(n=76)$ & 15 & 19.74 (11.05; 32.55) & & 35 & 46.05 (32.08; 64.05) & \\
\hline \multirow{2}{*}{$\uparrow \mathrm{DBP}^{3}$} & absent $(n=76)$ & 15 & 19.74 (11.05; 32.55) & \multirow{2}{*}{0.816} & 20 & $26.32(16.07 ; 40.64)$ & \multirow{2}{*}{$0.027 *$} \\
\hline & present $(n=44)$ & 10 & $22.73(10.90 ; 41.80)$ & & 21 & 47.73 (29.54; 72.96) & \\
\hline \multirow{2}{*}{$\downarrow \mathrm{HDL}^{-\mathrm{C}^{3}}$} & absent $(n=96)$ & 14 & 14.58 (7.97; 24.47) & \multirow{2}{*}{$0.002 *$} & 22 & 22.92 (14.36; 34.70) & \multirow{2}{*}{$<0.001^{*}$} \\
\hline & present $(n=24)$ & 11 & 45.83 (22.88; 82.01) & & 19 & 79.17 (47.66; 100.00) & \\
\hline \multirow{2}{*}{$\uparrow \mathrm{TG}^{3}$} & absent $(n=102)$ & 21 & 20.59 (12.74; 31.47) & \multirow{2}{*}{1.000} & 29 & 28.43 (19.04; 40.83) & \multirow{2}{*}{$0.003^{*}$} \\
\hline & present $(n=18)$ & 4 & $22.22(6.05 ; 56.90)$ & & 12 & $66.67(34.45 ; 100.00)$ & \\
\hline \multirow{2}{*}{$\uparrow$ Glucose } & absent $(n=85)$ & 16 & 18.82 (10.76; 30.57) & \multirow{2}{*}{0.460} & 18 & 21.18 (12.55; 33.47) & \multirow{2}{*}{$<0.001^{*}$} \\
\hline & present $(n=35)$ & 9 & 25.71 (11.76; 48.81) & & 23 & 65.71 (41.66; 98.60) & \\
\hline
\end{tabular}

Note. ${ }^{1}$ Qualitative data are presented as number (\% [95\% CI]). ${ }^{2 \uparrow}$ - increased parameter level; $\downarrow$ - decreased parameter level based on the metabolic syndrome criteria. ${ }^{3} \mathrm{CI}$ - confidence interval; AO - abdominal obesity; SBP - systolic blood pressure; DBP - diastolic blood pressure; HDL-C - high-density lipoprotein; TG - triglycerides. ${ }^{4} P-P$-value for difference tests between two proportions. ${ }^{5}$ *Statistically significant results 
Ta b le 6. Leptin levels in children with night eating syndrome and metabolic syndrome

\begin{tabular}{|c|c|c|c|c|c|c|}
\hline \multirow[b]{2}{*}{ Parameter } & \multicolumn{2}{|c|}{ Night eating syndrome } & \multirow[b]{2}{*}{$P$} & \multicolumn{2}{|c|}{ Metabolic syndrome } & \multirow[b]{2}{*}{$P$} \\
\hline & $\begin{array}{l}\text { present } \\
(n=25)\end{array}$ & $\begin{array}{c}\text { absent } \\
(n=95)\end{array}$ & & $\begin{array}{l}\text { present } \\
(n=41)\end{array}$ & $\begin{array}{c}\text { absent } \\
(n=79)\end{array}$ & \\
\hline $\begin{array}{l}\text { Leptin } \\
\text { level, ng/ml }\end{array}$ & $\begin{array}{c}4.98 \\
(3.65 ; 11.03)^{1}\end{array}$ & $\begin{array}{c}3.95 \\
(3.01 ; 6.39)\end{array}$ & $P_{\mathrm{M}-\mathrm{W}}^{2}=0.037 * 3$ & $\begin{array}{c}3.84 \\
3.08 ; 5.42)\end{array}$ & $\begin{array}{c}4.87 \\
(3.17 ; 8.68)\end{array}$ & $P_{\mathrm{M}-\mathrm{W}}=0.132$ \\
\hline $\begin{array}{l}\text { High leptin } \\
\text { level }\end{array}$ & $\begin{array}{c}n=9 \\
36.00 \\
(95 \% \text { CI } \\
16.46 ; 68.34)^{1}\end{array}$ & $\begin{array}{c}n=13, \\
13.68 \\
(95 \% \text { CI } \\
7.29 ; 23.40)\end{array}$ & $P_{\mathrm{F}}^{2}=0.018^{*}$ & $\begin{array}{c}n=8, \\
19.51 \\
(95 \% \text { CI } \\
8.42 ; 38.45)\end{array}$ & $\begin{array}{c}n=14, \\
17.72 \\
(95 \% \mathrm{CI} \\
9.69 ; 29.73)\end{array}$ & $P_{\mathrm{F}}=0.808$ \\
\hline
\end{tabular}

Note. ${ }^{1}$ Qualitative data are presented as number (\% [95 \% CI]), where CI is $95 \%$ confidence interval; quantitative data are presented as Me (Lq: Uq). ${ }^{2} P_{\mathrm{M}-\mathrm{W}}-$ level of statistical significance for Mann-Whitney test; $P_{\mathrm{F}}$ - level of statistical significance for Fisher exact two-tailed test. ${ }^{3}{ }^{*}$ Statistically significant results

Ta ble 7. Association of night eating syndrome and metabolic syndrome and its components in overweight and obese children

\begin{tabular}{l|c|c|c|c|c}
\hline \multicolumn{1}{c|}{ Parameter } & Estimate $^{2}$ & $\begin{array}{c}\text { Standard } \\
\text { Error }\end{array}$ & Wald $^{2}$ test & $P$ & OR $^{2}$ (95\% CI) \\
\hline Metabolic syndrome & 0.58 & 0.23 & 6.34 & $0.012^{* 4}$ & $3.21^{*}(1.29-7.94)$ \\
$\mathrm{AO}^{3}$ & 0.68 & 0.33 & 4.36 & $0.037^{*}$ & $3.90^{*}(1.09-14.02)$ \\
$\mathrm{SBP}^{3} \geq 130 \mathrm{~mm} \mathrm{Hg}$ & -0.09 & 0.23 & 0.15 & 0.698 & $0.84(0.34-2.06)$ \\
$\mathrm{DBP}^{3} \geq 85 \mathrm{~mm} \mathrm{Hg}$ & 0.09 & 0.23 & 0.15 & 0.698 & $1.20(0.48-2.95)$ \\
$\downarrow \mathrm{HDL}^{3}$ & 0.80 & 0.25 & 10.19 & $0.001^{*}$ & $4.96^{*}(1.85-13.24)$ \\
$\uparrow \mathrm{TG}^{3}$ & 0.05 & 0.31 & 0.02 & 0.875 & $1.10(0.33-3.70)$ \\
$\uparrow \mathrm{Glucose}^{3}$ & 0.20 & 0.238 & 0.71 & 0.400 & $1.49(0.59-3.80)$ \\
\hline
\end{tabular}

Note. ${ }^{\uparrow} \uparrow$ - increased parameter level; $\downarrow$ - decreased parameter level based on the metabolic syndrome criteria. ${ }^{2}$ Estimate - coefficient in logistic regression and its standard error, Wald chi-square test for statistical significance assessment and $P-P$-value for Wald test; OR - odds ratio and its $95 \% \mathrm{CI}$ - confidence interval. ${ }^{3} \mathrm{AO}$ - abdominal obesity; SBP - systolic blood pressure; DBP - diastolic blood pressure; HDL-C - high-density lipoprotein; TG - triglycerides. $4 *$ Statistically significant results

increased frequency of meal intake and more food consumed, which certainly lead to obesity [7, 24, 25]. Furthermore, the absence of night rest is accompanied by decreased physical activity during the working day and decreased energy expenditure $[7,26]$.

Circadian disturbances in the synthesis of neurogenic mediators and production of hormones (e.g., leptin, melatonin, serotonin, ghrelin, insulin, cortisol, prolactin, thyroid-stimulating hormone) have been discussed as the important causes of NES development [7, 27]. Changes in circadian-induced behavior (sleeping and activity) have an impact on insulin resistance development, the appearance of dyslipidemia, and arterial hypertension which are the main components of MS [28, 29]. Decreased sleep duration leads to decreased leptin production. Leptin is a powerful antiorexigenic factor; as a result of decreased leptin, appetite will be stimulated [30]. Leptin resistance could explain the increased leptin level in cases of NES [31]. At the same time, leptin resistance is typical for MS. Simultaneously, the appetite is stimulated due to decreased serotonin synthesis because of disturbed sleep patterns. Sleep deficiency leads to inflammation and oxidative stress, which could later contribute to the development of impaired glucose tolerance and type 2 diabetes [26].

The association between NES and obesity could also be explained by genetic factors such as clock gene mutations or variations in serotogenic genes [7, 32]. Nevertheless, these studies are still ongoing and need further clarification. Genetic sus- 
ceptibility to NES could be confirmed with a higher prevalence of this type of eating disorder among youth whose mothers have also suffered from NES [11]. It is known that MS also has a genetic predisposition, which manifests as genetic peculiarities of leptin synthesis and structure of its receptors, adiponectin gene defects, disturbances in the genes encoding TNF- $\alpha$, IL- 6 , adrenergic receptor $\beta 3$, and genes responsible for lipid metabolism (liver $\mathrm{X}$ receptor, retinoid $\mathrm{X}$ receptor, peroxisome proliferatoractivated receptor gamma, apolipoprotein A5) [33].

Additionally, the appearance of obesity in cases of NES could be explained by the presence of unfavorable mental status, dysphoria, and depression $[34,35]$.

Our research did not find any differences in BP levels between groups of children with diagnosed NES and in groups without this eating disorder. Nevertheless, the association between arterial hypertension and NES could be explained by the stimulating effect of insulin on the sympathetic nervous system and activation of the renin-angiotensin-aldosterone system [36, 37]. Dyslipidemia in cases of NES is the result of $\mathrm{AO}$, insulin resistance, and changes in the circadian rhythms of hormone synthesis [38, 39].

At the same time, the prevalence of MS among children is growing up. According to our study, MS prevalence was $39.80 \%$ among obese children and 9.09\% in overweight youth. Our data correlate with the results of American researchers who have noted the prevalence of MS was $29.2 \%$ in obese children and $11.9 \%$ in overweight ones [40]. The occurrence of MS in the pediatric population due to obesity is considered to be an unfavorable cardiovascular prognostic factor [41]. Based on the current studies, MS development in childhood cannot be solely explained by the presence of $\mathrm{AO}$. It should be emphasized that MS occurrence is the result of complex pathophysiological influences, such as insulin resistance, production of pro-inflammatory cytokines, and imbalance of adipokines (leptin, adiponectin), THF- $\alpha$, and IL6 , as well as endothelial dysfunction and circadian rhythm disruption [40-42].

Strengths of our study are its cross-sectional character and assessment of one specific patient cohort (overweight/obese children). However, our study has some limitations. It was performed at Ternopil Regional Hospital, and therefore, the gender distribution of participants was not the same as in the general population (number of girls was significantly smaller). A second limitation was that the type and quantity of food which was taken in the evening and at night were not taken into account.

Conclusions. MS and NES in the overweight/ obese study group are different disorders with different diagnostic criteria but with the similar pathophysiological factors and health-related consequences. The emergence of MS on the basis of NES is explained by the development of AO, which is a key component of MS. AO in cases of NES is the result of disrupted hormonal circadian rhythms, as well as increased food consumption in the evening and night with a decreased energy expenditure, correspondingly. In turn, AO and insulin resistance lead to the development of hypertriglyceridemia, decreased HDL-C levels, hyperglycemia, and arterial hypertension.

Careful screening for eating behavior and especially NES should be an integral part of the examination of children with overweight and obesity with the aim of timely diagnosis of MS.

Conflict of interest. Authors have completed the Unified Conflicts of Interest form at http://ukrbiochemjournal.org/wp-content/uploads/2018/12/ coi_disclosure.pdf and declare no conflict of interest

Funding. The research was supported and funded by the Ministry of Health of Ukraine (Project No 0120U104283).

Acknowledgments. We thank Cedars-Sinai Medical Center's International Research and Innovation in Medicine Program, and the Association for Regional Cooperation in the Fields of Health, Science and Technology (RECOOP HST Association) for their support.

\section{ДОСЛІДЖЕННЯ ВЗАЕМОЗВ'ЯЗКУ МІЖ СИНДРОМОМ НІЧНОГО ВЖИВАННЯ ЇЖІ ТА МЕТАБОЛІЧНИМ СИНДРОМОМ У ДІТЕЙ}

\section{Г. А. Павлишин, К. В. Козак}

Тернопільський національний медичний університет ім. І.Я.Горбачевського МОЗ України ${ }^{\bowtie}$ e-mail: kozakk@tdmu.edu.ua

Порушення харчової поведінки - одна із причин розвитку ожиріння абдомінального типу та метаболічного синдрому. Якщо нещодавно синдром нічного вживання їжі та метаболічний синдром розглядалися виключно як нозологія 
характерна для дорослого населення, то наразі вони реєструються серед дитячої популяції. У дослідження включено 120 дітей (27 дівчаток $(22,5 \%)$ та 93 хлопчики (77,5\%) віком $10-17$ років із надмірною масою тіла $(18,33 \%)$ та ожирінням (81,67\%). Усім дітям проведено антропометрію та вимірювання артеріального тиску. Здійснено визначення в сироватці крові рівнів тригліцеридів, ліпопротеїнів високої щільності та глюкози. За результатами обстеження абдомінальне ожиріння виявлено у $70 \%$ дітей. Синдром нічного вживання їжі діагностовано у 20,83\% підлітків. Водночас, частота виявлення метаболічного синдрому в групі обстежених складала $34,17 \%$. Метаболічний синдром вірогідно реєструвався частіше в дітей із синдромом нічного вживання їжі $(56,00 \%$ (95\% CI 30,62; 93,96)) порівняно із $28,42 \%$ (95\% CI 18,73; 41,35) - у групі осіб без розладу харчової поведінки $(P<0,05)$. Результатами дослідження з'ясовано, що наявність синдрому нічного вживання їжі збільшує ймовірність виникнення метаболічного синдрому втричі (OR $3,21$ (95\% CI 1,29-7,94); $P=0,012)$. Таким чином, ретельний скринінг щодо виявлення порушень харчової поведінки і синдрому нічного вживання їжі, зокрема, має бути невід'ємною частиною обстеження дітей $з$ надмірною вагою та ожирінням для своєчасної діагностики метаболічного синдрому.

К л ю ч о в і с ло в а: синдром нічного вживання їжі, метаболічний синдром, діти.

\section{References}

1. World Health Organization. Obesity and overweight. WHO Available at https://www.who. int/mediacentre/factsheets/ fs311/en/ (accessed 2016).

2. Blüher M. Obesity: global epidemiology and pathogenesis. Nat Rev Endocrinol. 2019; 15(5): 288-298.

3. Styne DM, Arslanian SA, Connor EL, Farooqi IS, Murad MH, Silverstein JH, Yanovski JA. Pediatric obesity-assessment, treatment, and prevention: an endocrine society clinical practice guideline. J Clin Endocrinol Metab. 2017; 102(3): 709-757.

4. IDF consensus definition of the metabolic syndrome in children and adolescents / Alberti G, Zimmet P, Kaufman F, Tajima N, Silink M, Arslanian S, Wong G, Bennett P,
Shaw J, Caprio S. International Diabetes Federation, 2007. 24 p.

5. Weihe $\mathrm{P}$, Weihrauch-Blüher S. Metabolic Syndrome in Children and Adolescents: Diagnostic Criteria, Therapeutic Options and Perspectives. Curr Obes Rep. 2019; 8(4): 472479.

6. DeBoer MD. Assessing and Managing the Metabolic Syndrome in Children and Adolescents. Nutrients. 2019; 11(8): 1788.

7. Gallant AR, Lundgren J, Drapeau V. The nighteating syndrome and obesity. Obes Rev. 2012; 13(6): 528-536.

8. Bruzas MB, Allison KC. A Review of the relationship between night eating syndrome and body mass index. Curr Obes Rep. 2019; 8(2): 145-155.

9. Cleator J, Abbott J, Judd P, Sutton C, Wilding JPH. Night eating syndrome: implications for severe obesity. Nutr Diabetes. 2012; 2(9): e44.

10. McCuen-Wurst C, Ruggieri M, Allison KC. Disordered eating and obesity: associations between binge-eating disorder, night-eating syndrome, and weight-related comorbidities. Ann NY Acad Sci. 2018; 1411(1): 96-105.

11. Milano W, De Rosa M, Milano L, Capasso A. Night eating syndrome: an overview. $J$ Pharm Pharmacol. 2012; 64(1): 2-10.

12. Yoshida J, Eguchi E,Nagaoka K, Ito T, Ogino K. Association of night eating habits with metabolic syndrome and its components: a longitudinal study. BMC Public Health. 2018; 18(1): 1366.

13. Tanofsky-Kraff M, Shomaker LB, Stern EA, Miller R, Sebring N, Dellavalle D, Yanovski SZ, Hubbard VS, Yanovski JA. Children's binge eating and development of metabolic syndrome. Int J Obes (Lond). 2012; 36(7): 956-962.

14. Defining childhood obesity. Centers for Disease Control and Prevention. Available at https:// www.cdc.gov/obesity/childhood/defining.html (accessed 2018).

15. Allison KC, Lundgren JD, O'Reardon JP, Geliebter A, Gluck ME, Vinai P, Mitchell JE, Schenck CH, Howell MJ, Crow SJ, Engel S, Latzer Y, Tzischinsky O, Mahowald MW, Stunkard AJ. Proposed diagnostic criteria for night eating syndrome. Int J Eat Disord. 2010; 43(3): 241-247.

16. Statistica (data analysis software system), version 7.0. Available from Internet: www.statsoft.com. StatSoft, Inc., 2004. 
17. Microsoft Corporation. (2018). Microsoft Excel. Retrieved from https://office.microsoft.com/ excel.

18. Yahia N, Brown C, Potter S, Szymanski H, Smith K, Pringle L, Herman C, Uribe M, Fu Z, Chung M, Geliebter A. Night eating syndrome and its association with weight status, physical activity, eating habits, smoking status, and sleep patterns among college students. Eat Weight Disord. 2017; 22(3): 421-433.

19. Allison KC, Goel N, Ahima RS. Delayed timing of eating: impact on weight and metabolism. Curr Obes Rep. 2014; 3(1): 91-100.

20. Hernandez E, Kim M, Kim WG, Yoon J. Nutritional aspects of night eating and its association with weight status among Korean adolescents. Nutr Res Pract. 2016; 10(4): 448455.

21. Runfola CD, Allison KC, Hardy KK, Lock J, Peebles R. Prevalence and clinical significance of night eating syndrome in university students. J Adolesc Health. 2014; 55(1): 41-48.

22. Night eating syndrome: research, assessment, and treatment / Ed. JD Lundgren, KC Allison, AJ Stunkard. Guilford Press, 2012. 299 p.

23. Hakim F, Kheirandish-Gozal L, Gozal D. Obesity and Altered Sleep: A Pathway to Metabolic Derangements in Children? Semin Pediatr Neurol. 2015; 22(2): 77-85.

24. Reiter RJ, Tan DX, Korkmaz A, Ma S. Obesity and metabolic syndrome: association with chronodisruption, sleep deprivation, and melatonin suppression. Ann Med. 2012; 44(6): 564-577.

25. Katsa ME, Ioannidis A, Zyga S, Tsironi M, Koutsovitis P, Chatzipanagiotou S, Panagiotakos D, Sachlas A, Kolovos P, Routsi K, Pistikou AM, Kougioumtzi Dimoliani DE, Rojas Gil AP. The Effect of nutrition and sleep habits on predisposition for metabolic syndrome in greek children. J Pediatr Nurs. 2018; 40: e2-e8.

26. Depner CM, Stothard ER, Wright KP Jr. Metabolic consequences of sleep and circadian disorders. Curr Diab Rep. 2014; 14(7): 507.

27. Birketvedt GS, Geliebter A, Florholmen J, Gluck ME. Neuroendocrine profile in the night eating syndrome. Curr Obes Rep. 2014; 3(1): 114-119.

28. Stunkard A, Lu XY. Rapid changes in night eating: considering mechanisms. Eat Weight Disord. 2010; 15(1-2): e2-e8.
29. Canuto R, Garcez AS, Olinto MTA. Metabolic syndrome and shift work: a systematic review. Sleep Med Rev. 2013; 17(6): 425-431.

30. Crocker MK, Yanovski JA. Pediatric obesity: etiology and treatment. Endocrinol Metab Clin North Am. 2009; 38(3): 525-548.

31. Miller R, Tanofsky-Kraff M, Shomaker LB, Field SE, Hannallah L, Reina SA, Mooreville M, Sedaka N, Brady SM, Condarco T, Reynolds JC, Yanovski SZ, Yanovski JA. Serum leptin and loss of control eating in children and adolescents. Int J Obes (Lond). 2014; 38(3): 397-403.

32. Cecil J, Dalton M, Finlayson G, Blundell J, Hetherington M, Palmer C. Obesity and eating behaviour in children and adolescents: contribution of common gene polymorphisms. Int Rev Psychiatry. 2012; 24(3): 200-210.

33. Zafar U, Khaliq S, Ahmad HU, Manzoor S, Lone KP. Metabolic syndrome: an update on diagnostic criteria, pathogenesis, and genetic links. Hormones (Athens). 2018; 17(3): 299-313.

34. Riccobono G, Pompili A, Iannitelli A, Pacitti F. The relationship between night eating syndrome, depression and chronotype in a non-clinical adolescent population. Riv Psichiatr. 2019; 54(3): 115-119.

35. Guentcheva I, Dugas EN, Hanusaik N, Drapeau V, Sylvestre MP, O'Loughlin J. Depression symptoms and night eating in young adulthood. Eat Weight Disord. 2020; 25(6): 1593-1600.

36. Gangwisch JE, Feskanich D, Malaspina D, Shen S, Forman JP. Sleep duration and risk for hypertension in women: results from the nurses' health study. Am J Hypertens. 2013; 26(7): 903911.

37. Peach H, Gaultney JF, Reeve CL. Sleep characteristics, body mass index, and risk for hypertension in young adolescents. $J$ Youth Adolesc. 2015; 44(2): 271-284.

38. Garrido ALF, Duarte AS, Santana PT, Rodrigues GH, Pellegrino P, Nogueira LFR, Cipolla-Neto J, de Castro Moreno CR, Marqueze EC. Eating habits, sleep, and a proxy for circadian disruption are correlated with dyslipidemia in overweight night workers. Nutrition. 2021; 83: 111084.

39. Joo JH, Lee DW, Choi DW, Park EC. Association between night work and dyslipidemia in South Korean men and women: a cross-sectional study. Lipids Health Dis. 2019; 18(1): 75. 
40. Al-Hamad D, Raman V. Metabolic syndrome in children and adolescents. Transl Pediatr. 2017; 6(4): 397-407.

41. Weiss R, Bremer AA, Lustig RH. What is metabolic syndrome, and why are children getting it? Ann NY Acad Sci. 2013; 1281(1): 123140.
42. Zimmet P, Alberti KGMM, Stern N, Bilu C, El-Osta A, Einat H, Kronfeld-Schor N. The Circadian Syndrome: is the Metabolic Syndrome and much more! J Intern Med. 2019; 286(2): 181191. 